\title{
Kuyper se ekklesiologie en die interpretasie van 'kerklike sake' in artikel 30 van die Kerkorde van die Gereformeerde Kerke in Suid-Afrika
}

\author{
J.M. Vorster \\ Dept. Ekklesiologie \\ HTS/PU vir CHO \\ POTCHEFSTROOM
}

\begin{abstract}
The Ecclesiology of Abraham Kuyper had a visible influence on the Reformed Churches of South-Africa. Il has been noted by various theologians that his view of the Church as organism and as institute constituted the way in which these Churches functioned in South African society. His view determined the way in which the expression ecclesiastical matters in article 30 of the Church Order of the Reformed ('hurches in South Africa has been interpreted over the years. Ecclesiastical matters have heen interpreted as matters dealing with the institute itself. while political and social mallers have heen regarded as extra-ecclesiastical issues.

This article discusses the dilemma in the social calling of the Church which resulted from the application of the model of Kuyper. In this article another point of departure to the understanding of ecclesiastical affairs is suggested, namely the Kingdom of (jod. From the perspective of the Kingdom, ecclesiastical affairs should be defined broadly as the ethical teachings of the Word of God itself. The agenda of ecclesiastical assemblies should, therefore, inc/ude all isswes regarding the ethical principles of the Kingdom. These isswes should be dealt with in an ecclesiastical way, that is, applying a biblical foundation when preaching in the local church or taking resolutions by najor assemblies of churches.
\end{abstract}

\section{Inleidend}

Die ekklesiologie van Kuyper bly na 'n eeu nog steeds 'n belangrike en veelbesproke tema in die gerefonneerde teologie in Suid-Afrika. Veral in die huidige herbesimning oor die wese en taak van die kerk in 'n toekomstige SuidAfrika kom Kuyper se invloed weer onder die vergrootglas. Jonker (1989:12) het onlangs weer die pluriformiteitsleer van Kuyper ondersoek omdat hy meen dat Kuyper met sy pluriformiteitsleer 'n instrument aan die Suid-Afrikaanse 
gereformeerde teoloë gegee het om aparte kerke onder aparte volke teologies te regverdig, hoewel Kuyper self die eenheid, suiwerheid en kontekstualiteit van die belydenis in die oog gehad het.

Vroeër het Buys (1970:171) ook aangetoon dat 'n ander aspek van Kuyper se ekklesiologie, naamlik die onderskeiding instituut en organisme sowel die Gereformeerde Kerken in Nederland as die Gerefonmeerde Kerke in Suid-Afrika 'gestruktureer' het. Daarmee bedoel hy dat die roepingsvervulling van die kerke binne die raamwerk van die ekklesiologiese model geskied het. Die Gereformeerde Kerken in Nederland het intussen onder druk van 'n gesekulariseerde samelewing 'n ander weg opgegaan (Gereformeerde Kerken in Nederland, 1973: 55). Die Gereformeerde Kerke in Suid-Afrika funksioneer egter nog grotendeels binne hierdie model wat homself op kerklike vergaderings manifesteer in ' bepaalde interpretasie van artikel 30 van die Kerkorde van die Gereformeerde Kerke in Suid-Afrika. Hierdie artikel sê onder andere: "Kerklike vergaderings moet alleen kerklike sake en dit op kerklike wyse behandel ..." (Gereformeerde Kerke in Suid-Afrika, 1979:20). Die vraag is: Wat is die konkrete gevolge van die interpretasie van 'kerklike sake' met Kuyper se model as vertrekpunt? En kan daar 'n ander interpretasie van 'kerklike sake' moontlik wees? Hierdie vrae is tans weer belangrik, veral ondat dit die roeping van die kerke in die veranderende Suid-Afrika wesentlik raak en daarom word hierdie vrae in hierdie artikel onder die soeklig geplaas.

\section{Kuyper se beskouing}

Kuyper se beskouing oor die kerk as instituut en die kerk as organisme moet gelees word saam met sy onderskeiding van sighare en onsigbare kerk. Daar moet ook rekening gehou word met die ontwikkeling in sy ekklesiologie. Die onsigbare kerk was vir hom die sooma van Christus vir sover dit nog verborge is (Kuyper, 1909:205). Hierin het hy veral aangesluit by die Westminster-konfessie (Kuyper, 1943:61). Die sigbare kerk is die kerklike instituut. Aanvanklik het hy die onsigbare kerk die organisme genoem en die sigbare kerk die instituut (Velema, 1991:296). Later sien hy die universele gemeenskap van gedooptes as die sigbare organiese kerk of die kerk as sigbare 'orgaan'. Die sigbare kerk het twee bestaansvorne, naamlik die instituut en organisme (Kuyper, 1909:IIl:204). Die organisme is daar waar die gelowiges in die samelewing teenwoordig is. Die instituut is die amptelike organisasie van die gelowiges "voor zoover ze door afzonderlijke inrichting tot specifieke formatie is gekomen" (Kuyper, 1943:63). Die instituut is dan die aardse manifestasie van die hemelse onsigbare kerk. Die roeping van die kerk as instituut is die diens van die Woord en wat daarnee saamhang terwyl die organisme as doelpunt het die 'uitstraling' van die Woord op die samelewing (Kuyper, 1932:272). 
Kuyper se verset teen die volkskerkgedagte van die Nederlandse Hervormde Kerk het hom tot hierdie onderskeiding gebring. Die volkskerk beteken volgens hom "heel het volk, heel het natie door den Doop in de kerk van Christus is in te lijven" (Kuyper, 1932:II:268). Die volk moet op hierdie wyse deur die ampsdraers bereik word en daarom moet die volk binne die kerkmure bedien word. Hierdie beskouing lei, volgens Kuyper, nie slegs tot groot geestelike verval nie, maar bring ook die wêreldse die kerk binne, want die 'wet' van die volkskerk sê: Wat gis in die vaderland, moet weer gis in die kerk.

Teenoor die volkskerkgedagte stel hy dan die kerk as instituut wat die Woord moet bedien. Dit is die belangrike saak want:

Al brandt de lamp der Christelijke religie alleen binne de wanden van dat instituut, haar licht straalt door de vensters zeer verre daarbuiten uit, en werpt zich op al de geledingen en verbindingen van ons menselijk leven die in allerlei uitingen van menselijk leven en menselijk werksaamheid uitkomen (Kuyper, 1932:272).

Die kerstening van die samelewing, die Cliristelike lig op kuns, wetenskap en tegniek lê op die terrein van die organisme, terwyl die instituut besig moet bly met die bediening van die Woord en sakramente.

Hiermee het Kuyper nie net 'n alternatief vir die volkskerkgedagte gestel nie, maar 'n sintese bewerkstellig tussen die ekklesiologiese beskouings van die etiese en konfessionele rigtings van sy tyd (Smit, 1989:30). Sy beskouing het baie aandag getrek en het onder andere ook neerslag gevind in die samelewingsleer van die Wysbegeerte van die Wetsidee. Hierdie samelewingsleer het in gereformeerde kringe 'n bepaalde beskouing oor die roeping van die geinstitueerde kerke tot gevolg gelıad en dit is nodig om ook hierop te let.

\section{Die beskouing van die Wysbegeerte van die Wetsidee}

Dooyeweerd (1936:IIl:451) het filosofies voortgebou op Kuyper se ekklesiologiese onderskeidinge. Hierop het Botha (1971:136) en Schilder (s.j.: 97) in breedvoerige kritiese besprekings gewys. Dooyeweerd het, soos Kuyper, ook onderskei tussen die ecclesia invisibilis en ecclesia visibilis, hoewel hy nie met die terminologie vrede het nie. Die ecclesia invisibilis is die religieuse wortelgemeenskap in Christus (Dooyeweerd, 1946:11I 48a). Hierdie ecclesia invisibilis is bo-tydelik.

Die ecclesia visibilis bevat al die menslike samelewingstrukture en een van hierdie samelewingstrukture is die 'kerkinstituut'. Die verhouding tussen die kerkinstituut en die ander verbande is ' $n$ verhouding van gelykwaardigheid omdat almal 'n gemeenskaplike religieuse wortel het, naamlik die ecclesia invisibilis. 
Hierdie tydelike strukture is ook onderling onvervangbaar. Elkeen is soewerein in eie kring met ' $n$ eie bestemmingsfunksie; tog is elkeen kragtens die gemeenskaplike religieuse wortel ook op mekaar aangewys.

Die bestemmingsfunksie van die tydelike kerkinstituut lê vir Dooyeweerd (1936: III:481) in die pistiese, en daarom is die kerkinstituut die "moeder van ons geloof in Jesus Christus". Vir hierdie uitgangspunt beroep hy hom op Calvyn en Kuyper. Sodra die soewereiniteit in eie kring van die tydelike kerkinstituut geskend word, lei dit tot defonnasie van die kerk. Hy gee dus aan die kerkinstituut as samelewingsverband 'n eie, maar tog ook begrensde struktuur en funksie ten opsigte van ander samelewingsverbande. Die kerkinstituut is vir Dooyeweerd (1936:III:486), wat struktuur aanbetref, 'n 'belydeniskerk' wat deur die diens van die Woord en sakramente die geloof moet laat groei.

Die konsekwensie van Dooyeweerd se samelewingsleer, wat hy hoofsaaklik bou op Kuyper se ekklesiologie, is dat die kerk as 'n instituut 'n 'Christelike samelewingsverband', tussen ander 'Christelike samelewingsverbande' is. Die taak van hierdie kerkinstituut is om die Woord te bedien, terwyl die ander samelewingsverbande Christelike kultuur moet positiveer. Die roeping van die geïnstitueerde kerk word hierin duidelik omlyn en beperk tot sake wat die 'instituut' self raak en nie inmeng op die terrein van ander 'Christelike samelewingsverbande' nie.

Kuyper se siening van die instituut en Dooyeweerd se filosofiese uitbouing daarvan in sy samelewingsleer het groot reaksie in Nederlandse en Suid-Afrikaanse gereformeerde kringe ontlok. Sommige van hierdie reaksies het ook interessante implikasies vir die interpretasie van 'kerklike sake' in artikel 30 van die Kerkorde. Terwille van 'n geheelbeeld word hieraan vervolgens aandag gegee.

\section{Kritiese reaksie in Nederland}

Nie al die kritiek op Kuyper wat oor die afgelope eeu ontwikkel het, het neerslag gevind in die gereformeerde teologie in Suid-Afrika nie. Daarom word hier nie op al die reaksies ingegaan nie. Wat vir die teologiebeoefening van teoloë binne die Gereformeerde Kerke in Suid-Afrika van belang was, was die kritiek van Van Leeuwen, Schilder en Velema.

Van Leeuwen (1946:218) het Kuyper se kerkbegrip indringend bestudeer, bespreek en beoordeel. Hy het die kritiek van die kant van die Nederlandse Hervormde Kerk by monde van Hoedemaker, Eerdmans, Hylkema, Haitjema en Van Ruler na waarde geskat, asook die kritiek van Ten Hoor, Beuker en Schilder uit die destydse kringe van teoloë binne die Gereformeerde Kerken in Nederland. Daarbenewens het hy as beoordelingsnorm die ontwikkeling van die Calvinistiese kerkbegrip van Calvyn beskryf (Van Leeuwen, 1946:237-251). 
Vanuit bogenoemde gesigshoeke het Van Leeuwen (1946:268) tot die konklusie gekom dat dit moeilik is on Kuyper se beskouinge Calvinisties te noem. Sommige elemente soos die verkiesing, kerklike instituut, prediking van die Woord en bediening van sakramente het wel duidelike elemente van Calvyn. Ander elemente kan nie na Calvyn teruggevoer word nie, soos onder andere die ekklesiologiese onderskeiding kerk as instituut en kerk as organisme. Van Leeuwen (1946:268) tipeer hierdie onderskeiding as Neo-Calvinisties. Calvyn se soepel benadering oor die wese en roeping van die kerk word volgens hom vervang met strakke onderskeidings en definisies. Van Leeuwen se kritiek op Kuyper is ook deur Botha (1971:147) saam met ander nuwe gesigspunte gebruik om die prinsipiële gebreke in die samelewingsleer van die wysbegeerte van Dooyeweerd aan te toon. Hierdie gebreke het Botha genoop om die oplossing te soek in die Bybelse koninkryksgedagte (Botha, 1971:161). Hierop word later teruggekom.

Die kritiek van Schilder was veel meer indringend en fundamenteel as dié van Van Leeuwen. Sy skerp kritiek rus eintlik in sy groot verskil met Kuyper se beskouing van algemene en besondere genade - Douma (1966:119) wys dit duidelik uit. Oor die ekklesiologiese onderskeiding van Kuyper het Schilder (s.j.: 97) gesê dat die kerk as organisme nie eintlik kerk genoem moet word nie, omdat 'n mens die gevaar loop dat jy die kerk telkens sien in verskillende gestaltes. Voorts meen hy dat Kuyper en die Wysbegeerte van die Wetsidee die kerk en die Koninkryk van God 'parallel' stel. Dit is nie duidelik wat Schilder met parallel bedoel nie omdat hy ook erken dat by Kuyper die onsigbare kerk "wat anders is dan het Koninkrijk der hemelen" (Schilder, s.j.:97). Dit is egter duidelik dat hy oortuig is dat die gedagte van die Koninkryk van God nie by Kuyper of die Wysbegeerte van die Wetsidee tot sy reg kom nie

Schilder (s.j.:98) gee as verdere rede waarom die organisme nie kerk genoem moet word nie, die Bybelse betekenis van die begrip ekklesia. Ekklesia beteken vergadering en daarom behoort instituering tot die wese van die kerk. Op hierdie tweede punt hou sy kritiek egter nie steek nie, omdat ekk/esia in die Nuwe Testament nie net wys op georganiseerde gemeentes nie, maar ook op gelowiges in die algemeen. Verskeie eksegete wys dit duidelik uit (Snyman, 1977:25; Schmidt, 1969:59; Pop, 1964:336; Lindijer, 1962:54 en De Graaff, 1968:59). Nietemin het Schilder groot gebreke in Kuyper se beskouing blootgelê en die aandag gevestig op die Bybelse perspektief van die Koninkryk. Schilder laat die Bybel self meer spreek. Hierdie positiewe bydrae het ook later sy neerslag in die ekklesiologiese ontwikkelinge binne die Gereformeerde Kerke in Suid-Afrika gevind.

Teoloë bimne die Christelijke Gereformeerde Kerk in Nederland se reaksie op Kuyper se beskouing is ook relevant vir latere ontwikkelings binne die Gereformeerde Kerke in Suid-Afrika, vanweë die nou teologiese en geestelike band wat 
sedert 1859 tussen die twee kerkverbande bestaan. In hierdie kring het veral Velema hom met Kuyper besig gehou: Velema (1991:298) erken dat hy vroeer slegs teen die terminologie instituut en organisme kritiek gehad het, maar dat die saak vir hom aanvaarbaar was. Hy het dit selfs 'n "geweldige greep" genoem (Velema, 1991:297). Later het hy meer krities geword oor die saak self. Sy kritiek spits veral toe op die ekklesiologiese gevolge van Kuyper se beskouing. Die belangrikste hiervan is dat die kerk as instituut deel van sy plig afskuif op die skouers van die gelowiges. Verder lei dit daartoe dat allerlei organisasies met die kerk en 'kerklidmaatskap' verbind word sonder betrokkenheid van die kerklike instituut. Hierdie tweede kritiekpunt van Velema word nie voldoende beredeneer sodat dit duidelik is wat hy daannee bedoel nie Die argument word dus nie verder gevoer nie. Sy eerste kritiekpunt is egter wesensbelangrik. Met sy ekklesiologiese onderskeiding het Kuyper die instituut se roeping vereng en die grootste deel verplaas na die organisme. In die praktyk het dit gelei tot 'n onaktiewe 'vergeestelikte' kerk, terwyl allerlei maatskaplike, sogenaande Christelike organisasies op die 'gebied van die organisme' ontstaan het. Daanmee saam is die begrip kerklike sake gedefinieer as net dié sake wat betrekking het op die instituut in sy verengde betekenis - 'n siening wat die maatskaplike roeping van die geïnstitueerde kerk wesenlik aantas.

Velema (1991:306) wil as uitweg uit die dilemma eerder praat van die roeping van die Christen as van die roeping van die kerk as organisme en grond dit op die Skrifgedeeltes soos 1 Petrus 2:4-10, Matteus 5:15 en 16 en Filipense 2:14-16. Die werk in dié gedeeltes vermeld, word verrig deur die gelowiges wat behoort tot die volk van God. Hy onderskei tussen kerk en gelowige, maar waarsku teen 'n skeiding van "die kerk in haar amptelijke gestalte" en "organiese kerk in die wereld" (Velema, 1991:307).

Uit die kritiek in Nederland op die beskouing van Kuyper en die Wysbegeerte van die Wetsidee van Dooyeweerd het twee belangrike sake uitgekristalliseer, naamlik die gebrek aan 'n Koninkryksperspektief op die kerk en die onhoudbare verenging van die instituut wat ook lei tot 'n verenging van 'kerklike sake' op kerklike vergaderings. Op ander kritiekpunte op Kuyper se kerkbeskouing word nou nie verder ingegaan nie, ondat dit vir die behandeling van hierdie tema nie ter sake is nie. Bogenoemde twee kritiekpunte is wel van groot belang vir die omskrywing van 'kerklike sake' op kerklike vergaderings en die gevolglike siening van die roeping van die geinstitueerde kerk.

\section{Kritiese reaksie in Suid-Afrika}

Die Suid-Afrikaanse kritiek op Kuyper se beskouing het veral vanuit die filosofiese en dogmatiese kringe gekom. Omdat in elkeen van hierdie dissiplines 'n ander vertrekpunt geld, word elkeen afsonderlik kortliks bespreek. 


\subsection{Filosofiese kritiek}

Uit hierdie hoek het Botha en Duvenage Kuyper en die Wysbegeerte van die Wetsidee se beskouing onder die vergrootglas geplaas. Botha (1971:156) sien skolastiese elemente in die denkbeelde van Kuyper wat na vore kom in sy liefde vir dichotomistiese onderskeidinge van sigbaar-onsigbaar, algemeen-besonder en organisme-instituut. Sy toon aan dat Dooyeweerd hierdie "gereformeerdskolastiese" elemente oorgeneem het. Soos De Graaff (1968:63) is sy van mening dat by Kuyper en Dooyeweerd die kerk in "sentraal religieuse sin", dit wil sê, die onsigbare kerk, gekontrasteer word met die instituut. Die instituut word dus gerelativeer. Soos reeds aangedui, soek sy die oplossing in 'n Koninkryksperspektief op die kerk, waarin die eie-aard en roeping van die geïnstitueerde kerk uitgewerk moet word.

Duvenage (1962:53-55) wil nie die beskouing van die Wysbegeerte van die Wetsidee loslaat nie, maar wil tog korreksies aanbring. Ook in aansluiting by die Westminsterkonfessie sê hy dat die kerk 'n "onsigbare aspek" het wat insluit "die kerk se bo-tydelike oorsprong (uitverkiesing); die bo-tydelike grondvester Christus, wat as tweede Adam die Verlosser en Koning van sy Kerk is en die botydelike vervulling in die voleinding van die eeue wanneer die ontelbare skare die nuwe aarde sal beërwe".

Hy sê verder dat die sigbare kerk die tydelike aspek is van die onsigbare kerk en dat die sigbare kerk gesien moet word as die geheel van die openbaring van die onsigbare kerk of die Koninkryk van die hemele in die tyd - en dit omvat alle gestaltes van die lewe in Clristus. Daartoe behoort dan die Clristelike gesin, die Christelike staat, die Christelike skool en die 'Christelike kerkinstituut'. Die 'geinstitueerde kerk' is een deel of vorm van die kerk (Duvenage, 1962:63).

Hoewel Duvenage kritiek het op Kuyper, kom hy nie verder nie as om te sê dat die terme kerk as organisme en kerk as instituut aanleiding gee tot misverstand en dat die twee begrippe eintlik teenoor mekaar gestel word en geskei word. Hy vra egter ook meer aandag vir die gedagte van die Koninkryk en gebruik die beeld van konsentriese sirkels om 'n samelewingsleer binne Koninkryksperspektief uit te werk (Duvenage, 1969:128). In hierdie korreksie op Kuyper ontkom hy egter nie aan die verenging en relativering van die geïnstitueerde kerk nie.

\subsection{Dogmatiese kritiek}

Die deeglikste analise en beoordeling van Kuyper se beskouing deur teoloë in Suid-Afrika is gedoen deur Buys (1970:172). Hy spreek waardering uit vir die grootsheid van Kuyper se konsep en die feit dat Kuyper die gedagte van 'n volkskerk afgewys het. Hy sien Kuyper se beskouing as 'n poging om die kerk- 
like instituut van staatsoorheersing te bevry sonder om die roeping van die kerk teenoor die volk prys te gee. Hy wou die kerk vry hou van verwêreldliking.

Buys (1970:197) sluit hom egter ook aan by die kritiek van Duvenage en De Graaff teen Kuyper se terminologie. Tog meen hy dat die inhoud daarvan sover dit as terrein-onderskeiding bedoel is, nie strydig is met die Skrif en die gereformeerde belydenis nie. Hy wil 'n ander weg soek, maar met behoud van die saak wat Kuyper onder die aandag bring (Buys, 1970:200).

Soos Kuyper praat Buys (1970:200) ook van die tweërlei roeping van die kerk. Wie oor die kerk besin, moet by God Drie-enig begin. Die roeping van die kerk moet op die roeping van Christus berus. Die roeping van Christus bestaan uit die byeenbring van alle uitverkorenes onder één Hoof en die byeenbring van alle dinge onder een Hoof. Eersgenoemde behels die realisering van die uitverkiesing on mense te bring om God te dien. Laasgenoemde behels die herstel van die sondige skeppingsorde. In aansluiting by Honig noem hy hierdie roeping die kosmologiese taak van Christus (Buys, 1970:207).

Soos Christus het die kerk dan ook tweërlei roeping. Enersyds het die roeping betrekking op die uitverkorenes in besonder en andersyds het die roeping betrekking op die wêreldorde (Buys, 1970:213). Hierdie onderskeiding bring Buys daartoe om deurgaans oor die tweërlei werkwyses en openbaringswyses van die kerk te praat. Die tweërlei werkwyse bestaan uit die institutêre werkwyse wat die bediening van die genademiddels behels en die buite-institutêre werkwyse wat deur middel van die amp van die gelowige geskied. Vir hierdie standpunt beroep hy hom op Veldkamp en Bavinck se verklaring van die Heidelbergse Kategismus Sondag 12 (Buys, 1970:237). Later noem hy dit die soteriologiese en kosmologiese roeping van die kerk.

Anders as Schilder en Duvenage bring Buys nie die Koninkryk van God in die gesigsveld nie, hoewel hy die kosmologiese roeping van die kerk erken wat deur die gelowiges uitgevoer word. Wat is die implikasies hiervan vir 'kerklike sake' op die agenda van meerdere vergaderings? Dit kan tog nie net met die soteriologiese te doen hê nie. Buys se kritiek op Kuyper is waardevol maar dit blyk dat hy ook nie die verskraling van die roeping van die geïntitueerde kerk, soos by Kuyper, ontvlug nie.

\section{Kerkregtelike implikasies}

\subsection{Historiese agtergrond van artikel 30 Kerkorde}

Die oorsprong van die bewoording van artikel 30, naamlik "kerklike sake op 'n kerklike wyse" lê in 'n versoek wat Marnix van St. Aldegonde aan die Sinode van Emden (1571) gerig het. Hy het die hulp van die Sinode gevra in Prins Willem se 
stryd teen Roomse Spanje (Van Dellen \& Monsma, 1954:135). Die Sinode het oor die versoek geswyg maar die Sinode van Dordrecht (1574) het die beginsel openlik gestel. In 1581 het die Sinode Middelburg die redaksie van die artikel vasgestel (Jansen, 1923:139).

Die invloed van die Franssprekende gereformeerdes by die Sinode van Emden was sterk (Pont, 1981:92). In hulle hantering van die versoek van Marnix kan Calvyn se invloed gesien word. Calvyn het hom sterk verset teen die RoomsKatolieke Kerk se oorheersing van die samelewing: die Rooms-Katolieke Sinode van Clairmont (1095) het byvoorbeeld besluit om 'n kruistog te onderneem, die vyftiende Konsilie van Wenen het besin oor oorlog met die Sarasene, die kerk het seggenskap oor alle dinge gehad (Bouwman, 1970:II:29). Calvyn het hom teen hierdie outoritêre besluitneming verset. Hy het egter, vanweë sy eie soepel kerkbeskouing, nie 'n rigiede skeiding gemaak tussen 'kerklik-institutêre' en 'buiteinstitutêre' sake nie. Sy uitgangspunt was die Woord, en die kerk kon volgens hom sê wat die Woord sê (Calvyn, 1949,III:163). Die Woord kan egter nie institutêr ingeperk word nie.

Bouwman (1970:II:29) dui aan hoe die uitdrukking kerklike sake na Calvyn en die Sinode van Enden (1571) op 'n soepel wyse hanteer is. Die onderskeid tussen 'kerklike sake' en ander maatskaplike sake was vaag. Hy wys op verskeie geleenthede in die Nederlandse geskiedenis waar daar ook ander sake bespreek is ondat politieke sake ten nouste met die lewe van die kerk saamhang. Met Kuyper se beskouing het 'n enger visie ingetree wat deur kerkregtelikes in Nederland en Suid-Afrika ingedra is.

\subsection{Kerklike sake in 'kerksentriese' perspektief}

Die kritiek uit filosofiese en dogmatiese kringe teen Kuyper se beskouing het nie noemenswaardig neerslag gevind in die gereformeerde kerkreg nie. Kerklike sake word in die gereformeerde kerkreg nog oor die algemeen gedefinieer teen die agtergrond van die beperkte taak van die kerk as instituut soos dit dëur Kuyper en die Wysbegeerte van die Wetsidee omskryf is.

In hierdie opsig kan veral verwys word na die standpunte van Rutgers (1921: 254); Jansen (1923:138) en Bouwman (1970:II:3I). Hierdie kerkregtelikes het onkrities die Kuyperiaanse spoor in hierdie opsig gevolg. Die kerk as instituut moet volgens hulle die pilaar van vastigheid en waarheid wees. Sake wat op kerklike vergaderings dien, kan dus slegs te doen hê met sake wat die instituut self raak, soos die welsyn van die kerk, die opbou van die geloof en die tuguitoefening. Kerklike sake word dus 'kerksentries' gedefinieer. Dieselfde redeneringswyse word gevind by Van Dellen en Monsma (1954:135). 
Die interpretasie van 'kerklike sake' met as uitgangspunt die Kuyperiaanse model en samelewingsleer van die Wysbegeerte van die Wetsidee, bring dus vir die geinstitueerde kerk 'n dilemma mee. Net dit wat die werkwyse van die 'instituut' raak is 'kerklike sake'. Bybelse getuienis ten opsigte van die samelewing lê op die skouers van die organisme oftewel die gelowiges binne die onderskeie 'samelewingsverbande'. Die geinstitueerde kerk boet getuienis in ondat die agendas van meerdere vergaderings gereduseer word tot 'geestelike sake'.

Die dilemma het hom in die Gereformeerde Kerke in Suid-Afrika uitgewys soos blyk uit die feit dat die definiëring van 'kerklike sake' by twee Sinodes van die Gereformeerde Kerke in Suid-Afrika aandag ontvang het - die Sinode van 1916 (GKSA, 1916:93) en die Sinode van 1942 (GKSA, 1942:22). Dit is opmerklik dat die noodsaak om oor die saak te besin spruit uit die politieke en maatskaplike omstandighede van die betrokke periodes. In 1916 het die pas afgelope Rebellie 'n rol gespeel. Die Sinode het dit nodig gevind om 'n brief aan die regering van die toenmalige Unie van Suid-Afrika te rig en te vra vir die vrylating van die rebelle in die gevangenis ondat dit "verder zal meewerken tot herstelling van de onderlinge vrede en de openbare rust, zo onmisbaar voor de welvaart van Kerk en Staat" (GKSA, 1916:82). Met verwysing na artikel 30 van die Kerkorde het dieselfde Sinode advies uitgereik ten opsigte van die reg tot verset teen die owerheid.

Sinode 1942 het breedvoerig gehandel oor die roeping van die kerk in die volkslewe en in hierdie proses toegespits op die 'kerklike sake' van artikel 30 van die Kerkorde. Die Sinode (1942:25) stel dat die saak histories verklaar moet word en nie in absolute sin opgeneem moet word nie. So word gewys op die feit dat gereformeerde kerke in dae van vervolging lulle ook met politieke kwessies ingelaat het, maar dat dit geskied het omdat Rome die politieke mag se hulp ingeroep het om die Reformasie teen te werk. Die Sinode erken dat sosio-maatskaplike eise betrokkenlıeid van die kerk kan opeis. Die uiteindelike standpunt van die Sinode is insiggewend en lui soos volg:

1. Dat die Here vir die kerk 'n opdrag gegee het naamlik die verkondiging van die Heilige Woord en wat daarmee verband hou (Matt. 28:19);

2. dat die kerk; veral in die prediking, geroep is om die lig van die Woord van God oor alle lewensfunksies te laat uitstraal en

3. dat daar gemengde sake is waarby kerk, staat en maatskappy gemeenskaplike belang het (GKSA, 1942:25).

Die roeping tot Bybelse getuienis in bepaalde konkrete omstandighede het 'n wyer interpretasie van artikel 30 van die Kerkorde geverg as wat die Kuyperiaanse model aanbied. Dit is opmerklik dat die Sinode 'n tipies Kuyperiaanse for- 
mulering van die kommissie wat die standpunt aanvanklik geformuleer het, gewysig het, naamlik, dat die terrein van werksaamheid van die kerk dié is van "partikuliere genade". Wat gemengde sake aanbetref, word dit aan die kerklike vergaderinge self oorgelaat wat die gemengde sake is en hoe die sake hanteer moet word (GKSA, 1942:26). Op hierdie patroon is baie sake daarna hanteer (Vorster, 1988:2). Albei Sinodes het, teen die agtergrond van besondere maatskaplike probleme, besef dat 'kerklike sake' nie eng gedefinieer kan word nie. Tog het die kerksentriese benadering, wat so opsigtelik was in die ekklesiologie via Kuyper, daama nog na vore gekom en was dit dikwels die oorsaak van die eintlike dilemma waarmee die vergaderings gesukkel het.

Van der Linde (1983:122) weerspieël ook hierdie dilemma met twee uitsprake in sy kommentaar op 'kerklike sake' in artikel 30 van die Kerkorde. Hy sê enersyds:

Op kerklike vergaderinge kan alleen kerklike sake, - alleen sake wat pas by die aard en doel van die kerk, behandel word. Die vergaderinge kan hulle nie met politieke, maatskaplike, militêre of wetenskaplike sake besig hou nie. Hulle moet alleen die kerk regeer, sodat die kerk kerk sal wees en bly.

Tog erken hy later:

Dit is dikwels moeilik om te bepaal of 'n saak op 'n kerklike vergadering tuishoort (Van der Linde, 1983:124).

Die eerste kerkregkundige binne die Gerefonmeerde Kerke in Suid-Afrika wat hom gedeeltelik bevry het van die kerksentriese definisie van 'kerklike sake' is Spoelstra (1989:181). In sy kerkbeskouing, en in samehang daannee, die siening van kerkreg en kerkregering, kies hy as uitgangspunt die Koningskap van Christus. Vanuit hierdie uitgangspunt reageer hy skerp op Kuyper se onderskeiding en die reste daarvan in die gereformeerde ekklesiologie. Ook verwerp hy Kuyper se onderskeiding van kerk as instituut en kerk as organisme as: "Legalisties en formeel en ('n onderskeiding wat) nie berus op Bybelse konfessionele en kerkregtelike gronde nie" (Spoelstra, 1990:354).

In sy verklaring van artikel 30 van die Kerkorde sê Spoelstra dat dit nie moet gaan om die standpunt van die kerk nie, maar om die standpunt van die Woord binne die perspektief van die Koninkryk. Hy waarsku teen 'n piëtistiese siening asof kerklike sake net geestelik is en wys daarop dat die artikel soms moeilik is om toe te pas (Spoelstra, 1989:181). Spoelstra soek die oplossing by Calvyn wat gesê het dat kerklike uitsprake moet gaan om die Woord. Hy bespreek egter nie die logiese konsekwensies van hierdie uitgangspunt nie. Bimne die Nederduitse Gereformeerde Kerk in Suid-Afrika begin veral Coertzen (1990:112) aandag vтa vir die kerkregtelike implikasies van die Koninkryk. Ten spyte van hierdie ontwikkeling was die benadering op meerdere vergaderings binne die Gereformeerde 
Kerke in Suid-Afrika egter nog in die onlangse verlede steeds 'kerksentries', soos veral die beredeneringe rondom die Nooitgedachtberaad (GKSA, 1988:73) en die Rustenburgberaad (GKSA, 1991:643) getuig.

'n Kerksentriese definisie van 'kerklike sake' in artikel 30 van die Kerkorde, op die patroon van Kuyper se beskouing oor die kerk as instituut, bring nie helderheid oor die roeping van die kerk nie. Soos aangedui, het gereformeerde dogmatici, filosowe en ekklesioloë tot die konklusie gekom dat die roeping van die geïnstitueerde kerk verskraal is met skadelike gevolge. Terselfdertyd het praktiese maatskaplike nood die Gereformeerde Kerke in Suid-Afrika gedurig gedwing tot ad hoc-optredes en inkonsekwente roepingsvervulling. Op hierdie inkonsekwente optredes is reeds elders gewys met die nodige dokumentasie (Vorster, 1988:2-12).

In die teenswoordige gereformeerde ekklesiologie word die kerk oinskryf en beredeneer binne die perspektief van die Koninkryk. Hierop is reeds gewys Myns insiens bied juis die Koninkryksperspektief 'n alternatief vir die kerksentriese definisie van die begrip 'kerklike sake', want daarin kan die antwoord op die Kuyperiaanse dilemma gesoek word

\section{3 'Kerklike sake' in Koninkryksperspektief}

Die Koninkryk is 'n baie sentrale Bybelse gedagte. Hoewel die tern nie in die Ou Testament gevind word nie, kom die saak baie duidelik voor, soos Du Toit (1969:11) en Vriezen (1966:144) aantoon. In die Nuwe Testament kom die saak onder ' $n$ verskeidenheid noemers baie duidelik voor en is dit inderdaad 'n grondlyn van die Nuwe Testament (Van der Walt, 1973:9). Van der Walt (1962:32) vat dié aspek van die Koninkryk saam in die volgende definisie

Die Koninkryk is iets wat kom (Matt. 6:10 par., Luk 11:2 ens.) en wel tot mense (Matt. 12:28 par.) - maar dis ook iets waartoe mense kom en ingaan (Matt. 5:20; 7:21; 18:3; Mark. 9:47 ens.).

Sentraal hieraan staan dus die regering van God en Christus, die Woord as 'wet' van die Koninkryk, die gelowiges as volk van die Koninkryk en die gelowige erkenning van God, as die terrein van die Koninkryk.

Die Koninkryk is ook besig om oral te kom waar mense en hulle werke gelowig buig voor die koningskap van Christus. Die gelowiges as volk van God Inanifesteer in die kerk as die sigbare konkrete gestalte van die Liggaam van Christus, en as gelowiges in die wêreld met 'n taak en roeping gerig op die koms van die Koninkryk. Dit is nie tweërlei roeping of tweërlei gestaltes van die kerk nie; dit is een roeping wat begin by die kerk en voortgesit word deur die gelowiges. Duvenage (1970:212) gebruik hiervoor die beeld van 'n kragstasie. Soos 
die kragstasie energie opwek om krag en lig te bring in 'n stad, so moet die geinstitueerde kerk deur die prediking van die Woord en deur die besluitneming op kerklike vergaderings die gelowige toerus vir sy roeping in die samelewing. So word God se werk in die individuele en gemeenskaplike lewe volvoer (Leith, 1990:226).

Die roeping van die gelowige raak die volle spektrum van die Koninkryk. Die gelowige moet oral die lig van die Woord laat skyn en die koningskap van Christus proklameer. Ook moet hy kerstenend werk in die gemeenskap op die terreine van politiek, kultuur, ekonomie en wetenskap - om slegs enkeles te noem. Kuyper het altyd 'n aspek beklemtoon en dit is 'n waardevolle bydrae van sy kerkbeskouing waarvoor sy kritici hom gelyk gegee het. Die vraag is egter: Kan daar dan 'n onderskeid gemaak word tussen die 'sake' wat in die prediking beklemtoon word en die 'sake' wat mag dien op 'n kerklike vergadering? Is die getuienis wat van kerklike vergaderinge deur besluitneming mag uitgaan enger as die prediking van die Woord binne die plaaslike kerk?

Kerklike sake moet soos die prediking te doen hê met alles waarom dit gaan in die koms van die Koninkryk. Prediking in die plaaslike kerk en kerklike getuienis in plaaslike kerk- en ekumeniese verband moet die konkrete toepassing van die beginsels van die Koninkryk uitspel vir die gelowiges om dit in sy werksfeer toe te pas. Dit alles moet egter geskied op 'n 'kerklike wyse', dit wil sê, deur getuienis. Die kerk kan deur sy besluite op meerdere vergaderinge Bybelse getuienis ten opsigte van die politiek laat hoor, maar hy word nie 'n politieke 'drukgroep' met 'n konstitusionele 'bloudruk' nie. Kerklike sake kan niks anders wees as Koninkryksake nie en is dan veel meer as net dit wat die 'instituut' raak.

Die roepingsvervulling van die Gereformeerde Kerke in Suid-Afrika is soms erg ingeperk deur 'n 'kerksentriese' defimiëring van 'kerklike sake' as gevolg van die sterk invloed van Kuyper se beskouing oor die kerk as instituut. In 'n tyd van groot maatskaplike veranderinge in Suid-Afrika sal die roeping van die kerke tot sy reg kom as die volle konsekwensies van die Koninkryk aanvaar word. Die Gereformeerde Kerke in Suid-Afrika se gesigsveld moet so ruim word soos die Koninkryk en uitsprei so ver as die reikwydte valu die Woord. Wat dus in die prediking aan die orde kan kom, hoort prinsipieel ook op die agenda van kerklike vergaderings as 'kerklike sake'.

\section{Bibliografie}

BOTHA, ME 1971 Sosio-kulturele metavrae Amsterdam Buijten en Schipperheijn

BOUWMAN, H 1970 Gereformeerd Kerkrecht Het recht der kerken in de praktijk. Kampen : Kok

BUYS, P.W 1970 Die ekklesiologiese onderskeiding Organisme en Instituut as antwoord op die problematiek van die Volkskerk 'n Historiese, prinsipiele en praktiese studie Potchefstroom PU vir $\mathrm{CHO}$ 
CALVYN, J, 1949. Institutie, of onderwijsing in de christelijke godsdienst. Delft : Meinema

COERTZEN, P 1990 Kerkordelike grense vir die kerk (In Du Toit, H \& Kruger, P red. Geroep tot eenheid. Halfway House : NG Kerkboekhandel. p. 111-126.)

DE GRAAFF, A. 1968. The Educational Ministry of the Church, a Perspective Grand Rapids: The Craig Press

DOOYEWEERD, H. 1936. De Wijsbegeerte der Wetsidee Amsterdam : Paris. 3 dele.

DOUMA, J. 1966. Algemene genade, uiteensetting, vergelijking en beoordeling van de opvattingen van A Kuyper, $\mathrm{K}$ Schilder en Joh. Calvijn over 'algemene genade' Kampen Oosterbaan en Le Contre

DU TOIT, S 1969. Die Koninkryk van God in die Ou Testament ( $/$ In Du Toit ea Die Koninkryk van God Potchefstroom : Pro Rege. p 11-33.)

DUVENAGE, S.C.W. 1962. Kerk, volk en jeug Die verhouding van Kerk tot volk Zaandijk : Heijnis

DUVENAGE, S.C.W. 1969. Die verhouding van Kerk en Koninkryk. (I/I du Toit, S e.a. Die Koninkryk van God Potchefstroom : Potch Herald p. 113-132)

DUVENAGE, S C W 1970 Die geinstitueerde kerk en die toekoms van die Afrikaanse volkskultuur Koers, 37 (3 en 4): 206-218, Feb

GEREFORMEERDE KERKE IN SUID-AFRIKA. 1916. Handelingen van de Synodale vergadering Pretoria : N D van der Reyden

GEREFORMEERDE KERKE IN SUID-AFRIKA 1942 Handelinge van die sewe-entwintigste sinodale vergadering van die Gereformeerde Gemeentes in Suid-Afrika Potchefstroom : Admin. Buro.

GEREFORMEERDE KERKE IN SUID-AFRIKA 1979. Kerkorde van die Gereformeerde Kerke in Suid-Afrika, soos gewysig deur verskillende sinodes. Potchefstroom Admin. Buro van die Gereformeerde Kerk

GEREFORMEERDE KERKE IN SUID-AFRIKA 1988 Handelinge van die drie-enveertigste Nasionale Sinode Potch Herald Potchefstroom

GEREFORMEERDE KERKE IN SUID-AFRIKA. 1991. Handelinge van die vier-enveertigste Nasionale Sinode te Potchefstroom : Admin. Buro.

GEREFORMEERDE KERKEN IN NEDERLAND 1973 en 1975 Programma ter bestrijding van het racisme, rapport aan de Generale Synode van Haarlem 1973-1975 van de G.K.N Opgestel deur die generale deputaten voor de Algemene Diakonale Arbeid, die Generale deputaten voor de zending en die Generale Deputaten Oecumene (Buitenland) Leusden Alg diensburo van die G K N Verw no 136

JANSEN, J 1923. Korte verklaring van die Kerkordening Kampen : Kok

JONKER, WD 1989. Die pluriformiteitsleer van Abraham Kuyper In die Skriflig, 23(3): 24-44.

KUYPER, A. 1909. Encyclopedie der heilige Godgeleerdheid Kampen : Kok 3 dele

KUYPER, A 1932 De Gemeene Gratie Deel 2 Kampen Kok

KUYPER, A 1943 Calvinism, Six Stone Foundation Lectures Michigan, Grand Rapids

W B Eerdmans

LEITH, J H 1990 Calvin's Doctrine of the Proclamation of the Word and Its Significance for Today ( $/$ h George, T ed John Calvin and the Church Louisville John Knox Press p. 226-241.)

LINDIJER, C H 1962 Kerk en Koninkryk Amsterdam : Ten Have

PONT, A D 1981. Die historiese agtergronde van ons kerklike reg Kaapstad HAUM

POP, F.J 1964. Bijbelse woorden en hun geheim, verklaring van een aantal Bijbelse woorden $s^{\prime}$-Gravenhage Boekencentrum, N V

RUTGERS, F.H 1921 Kerklijke adviesen (deel 1) Kampen: Kok

SCHILDER, K sj De Kerk Kampen : Copieerinrichting v d Berg, Broederweg 6 
SCHMIDT, K.L 1968 Ekklesia (In Kittel, G ed Theological Dictionary of the New Testament Michigan, Grand Rapids : Eerdmans 3:501-536.)

SMIT, C.J. 1989. Abraham Kuyper as kerkregkundige In die Skriflig, 23(3):24-44.

SNYMAN, W J. 1977. Nuwe en ou dinge, uit die skat van die Koninkryk. Pro Rege : Potchefstroom

SPOELSTRA, B 1989. Gereformeerde Kerkreg en Kerkregering 'n Handboek by die Kerkorde Hammanskraal : HTS.

SPOELSTRA, B 1990. 'n Ordeningsmodel vir kerke in kerkverband oor volks- en taalgrense heen In die Skriflig, 24(4) 353-377, Desember

VAN DELLEN, I \& MONSMA, M 1954 The Church Order Commentary Michigan, Grand Rapids : William B Eerdmans

VAN DER LINDE, G.P.L 1983. Die Kerkorde ' $n$ Verklaring van die Gereformeerde Kerkorde. Potchefstroom : Potchefstroomse Teologiese Publikasies

VAN DER WALT, T. 1962 Die Koninkryk van God - naby! Kampen : Kok.

VAN DER WALT, T. 1973 Openbaringsgeskiedenis van die Nuwe Testament 3 dele Potchefstroom Pro Rege

VAN LEEUWEN, P A 1946 Het kerkbegrip in de Theologie van Abraham Kuyper Franeker : Wever

VELEMA, W.H 1991. Kuypers conceptie van de kerk als organisme kritisch bekeken Theologia Reformata, 34 (4) 295-309, Des

VORSTER, J M 1988 Die roeping van die Gereformeerde kerke in die Suid-Afrikaanse politiek. In die Skriflig, 22(85):2-12.

VRIEZEN, Th C 1966 Hoofdlijnen der Theologie van het Oude Testament Wageningen H Veenman en Zonen 
